\title{
THE EFFECTIVENESS OF USING CHARADES GAME TOWARD STUDENTS' VOCABULARY MASTERY
}

\author{
Yulita Sahara Wati \\ yulitasaharawati@gmail.com \\ Muhammadiyah University of Metro, Indonesia \\ Aulia HanifahQomar \\ auliahanifahqomar@gmail.com \\ Muhammadiyah University of Metro, Indonesia
}

\begin{abstract}
This research aims to find out the effectiveness and significance different of using Charades game on students' vocabulary mastery at SMP Muhammadiyah Ahmad Dahlan Metro. Charades game is the activity that players try to guess a word phrase and their teammates. Charade game is a kind of game in which words are represented in pantomime. This research used experimental research. The subjects of this research are the eighth-grade students at SMP Muhammadiyah Ahmad Dahlan Metro academic year 2020. There are 20 students of the control group which used cluster random sampling techniques and 20 students of the experimental group. The research instrument used to collect the data in this research was test and observation. From the two classes, the experimental and control group, the measurement shows that the improvement of vocabulary mastery in the experimental group is higher than the control group. The result of the pretest score shows that the average score of the experimental group and the control group are 61,6and 66,6. From the score of both groups, the result shows that the control group is better than the experimental group. Then, the result of the posttest in the experimental group is higher than the control group; the average scores are 74,2 for experimental group and 68,8 for the control group. It can be concluded that there are effectiveness and significant differences in using Charades game in students' vocabulary mastery.
\end{abstract}

Keywords: Charades, Game, Vocabulary

\section{INTRODUCTION}

Vocabulary becomes the first

They can apply some of the ways to English basic knowledge to be mastered by improve English Vocabulary such as students. Without mastering vocabulary, watching English program, listening to students may not be able to make the English sentence. music and reading some kind of English book. A good mastery of vocabulary can 
help the learners in increasing the listening, speaking, reading and writing skills.

(Sudjana, N in Kosasih, 2014) states that the results of students' learning outcomes in school are influenced by two main factors, internal and external. Internal factor is from the student itself that influence the learning outcomes. Internal factors which include intelligence, interest, and attention to learning motivation and physical and health conditions.
Based on the pre-survey, the researchers investigate the English teacher of eighth grade SMP Muhammadiyah Ahmad Dahlan Metro and found some factors that make students feel difficulty in mastering vocabulary abilities. The first is internal factors, those are students got low scores in English subject, especially in mastering vocabulary. Besides that factor, there are external factors which make students lazy to learn English, it is the environment.

ideas, and feelings in communication. Vocabulary is the most important component language because it affects the four language skills, there are listening, speaking, reading, and writing. Related to the importance of vocabulary learning is central to language acquisition, whether the language first, second, or foreign. Generically, based on (Aslanabadi, 2013) a vocabulary usually grows and evolves with age, and serves as a useful and fundamental toll for communication and acquiring knowledge. Based on (Yunus et al.,2020) Teaching vocabulary is one of the basic elements in achieving all four language skills. (Brown, 2010) state that the

(Hariadi\& Amir, 2014) Vocabulary supports speakers to express their opinions, 
classification of words is classified based on functional words and content words.

Nunan in Orawiwatnakul students who have vocabulary mastery are the students who know multi-word, units, word families, and core meanings. It means that vocabulary should be mastered by the students. The students will get difficulties when they do not master the vocabulary.

From the definition above, the researcher concludes that vocabulary is a listing of all words that are taught in the foreign language. Vocabulary refers to the words that must understand to communicate effectively. Vocabulary is a word of a particular language including single words, compound words and idioms that individual speakers of a language might use.

\section{Charades Game}

Based on to (Bafadal, 2018), Charades means a game in which players guess a word or phrase from a written or acted clue given for each syllable and the whole item. (Syarfuni, 2010) states that Charades game is the activity that players a word phrase and their teammates try to guess. Charade game is a kind of game in which words are represented in pantomime.
Rafinggi \& Ihsan (2013) state that "charade game is a technique miming the individual parts of a word". It means that this game uses mime to know the meaning of words. Charade game can be conducted in pair or groups. When charade game is applied in groups, students are encouraged to think cooperatively, it makes them more comfortable in conducting activities in the classroom and outside. In other words, the charade game can facilitate students to learn vocabulary.

According to (Banerjee, 2014), charades means a game in which players guess a word or phrase from a written or acted clue given for each syllable and the whole item. Charades game the activity that players a word phrase and their teammates try to guess.

Based on Rafinggi \& Ikhsan (2013), the steps in teaching vocabulary by using Charades games as follows:

a. One player acts out something specific, such as pretending to be a certain animal or person or pretending to be doing a certain activity such as sewing, playing cards, watching and so on.

b. The other players try to guess whom the acting player working together in two, three or four miming a situation or activity while the other guess. 
c. You can have players working together in two, three or four miming a situation or activity while the other guess.

Furthermore (Himmele, 2011) states that this game takes them to activities of higher-level thinking.

The advantages of using Charades as a game in teaching vocabulary are:

1. Make the students work in a group and know the feeling of teamwork.

2. Make the students' to provide their

\section{METHODS}

This research used quantitative research because of the data in the form of numerical and statistical analysis. It includes experimental research. The types of experimental design used by the researcher are experimental design. (Sugiyono, 2013) explains that it is called true-experimental design (pure experiment) because, in this design, researchers can control all external variables that affect the experiment.

Sugiyono (2016) states that research variable is an attribute investigation, the variable is everything that planed by the researcher to learn. Variable is a constructor character to study that there are guessing, because everyone is curious when one player acts out the word.

3. Increasing students' activeness in acting the words or their activeness in guessing the words which are played

4. Increasing students' confidence in acting the words.

5. Help the students' to manage their emotions. They should not be nervous when acting out the words.

6. Classroom activity is more interesting and fun.

two kinds of variables in common, they are Independent variable and dependent variable. Independent variable is a variable that is affected or to influence another variable. The dependent variable is a variable that is affected or has become effect by Independent variable. In this study, two variables are used by the researcher, they are Independent $(\mathrm{X})$ and Dependent (Y) variable.

The researcher conducted "Charades game", as an independent variable to indicate the students' vocabulary mastery and in a dependent variable the researcher chose "students' vocabulary mastery". The researcher uses 
cluster random sampling as a technique to get an experimental class and control class. The researcher gives some steps, they are pre-test, treatment, and post-test.

Sugiyono (2016) states that the population is composed of the generalization: object or subject that has the quality and certain characteristics set by the researcher to learn and then make a conclusion. Therefore, the population of this research was the students on the eighth grade SMP Muhammadiyah Ahmad
Dahlan Metro in the academic year 2020/2021. (Setiadi, 2013) argues that the sampling technique is one of technique to take a sample, It is the sample selection in which all members of the population are naturally grouped in units, it states by Wiersma \& Jurs (2010). The researcher used random selection to determine which the class was the experimental group and the control group. The instrument of the research is a part of activities to detect accurate data.

\section{RESULTS AND DISCUSSION}

In this section, the researchers discuss the research findings which include the test result and the effectiveness of the treatment. The aim of the study finds out the effectiveness of using Charades Games for students' vocabulary mastery and to find out significance difference of the students' vocabulary mastery before and after being taught by using Charades Games for students' Vocabulary mastery in the eighth grade SMP Muhammadiyah Ahmad Dahlan Metro.

In this experiment, the researcher chooses the eighth-grade students of SMP Muhammadiyah Ahmad DahlanMetro in the academic year 2020/2021 as the subject of the research. There are two classes to be the sample which consists of 20 students for the experimental group and 20 students for the control group.

In this treatment, the researcher applied the Charades game. The researcher gave clear instruction to explain about Charades game. Before the game played, surely the researcher told the rules to the students. So, the students can understand clearly. After the students know the rules of the game, the researcher determined the theme that matches the current subject. 
Then, the students already in the charades game and guess the picture.

The researcher gave treatment in the control group without used charades game. The researcher applied an ordinary technique used in the daily lesson, such as explain the material. Then, the researcher gave the task to the students to discuss the unfamiliar vocabulary and found the meanings in the dictionary. Furthermore, the researcher corrected based on assessment rubric. Then, the researcher explained some unfamiliar vocabularies which did not found yet on their dictionary and the students noted the meaning.

The result of pre-test shows that the average score of the experimental group and the control group are 61.60 and 66.60. From the score of two groups, the result shows that the control group is better than the experimental group. However, the result of the post-test of the experimental group is higher the control group; they are 74.20 for the experimental group and 68.8 for the control group.

Furthermore, the hypothesis testing on the first hypothesis indicates that teaching English vocabulary using Charades game is effective to increase students' vocabulary mastery. The mean score of pretest in the experimental group is significantly higher than that of post-test. The experimental group of which the increasing mean score of vocabulary mastery was higher than the mean score of the pre-test. Then, It can be seen that the value of $t$ obtained (to) is higher than the value of $t$ table $(15.094>2.02)$.

Moreover, in the second hypothesis, hypothesis testing indicates that the experimental group is significantly higher than the control group. Based on the result of the investigation, it is found that there is any significant difference in vocabulary mastery between students taught using Charades Game and without using Charades Game. The experimental group of which the increasing mean score of vocabulary mastery was higher than control group showed this. It can be seen that the value of $\mathrm{t}$ obtained (to) is higher than the value of $\mathrm{t}$ table (2.325>2.02). The Charades Game is effective to increase the students' vocabulary mastery because it makes the students feel happy when playing this game. It is according to the theory proposed by (Himmele, 2011) stating that this game takes them to activities of higher-level thinking. It is also a lot of fun when students are asked to do this in a group. By using the game students are encouraged to think done in groups, in makes them more comfortable in 
conducting activities in the classroom and outside, and using this game will facilitate them to learn vocabulary.

The Charades Game is more effective in teaching vocabulary mastery because of some reasons: Firstly, it makes the students work in a group and know the feeling of teamwork. Secondly, it makes the students provide their own guessing because everyone is curious when one player acts out the word. Thirdly, it increases students' activeness in acting the words or their activeness in guessing the words which are played. Fourthly, it can increase students' confidence in acting the words. Fifthly, this

\section{CONCLUSION}

The use of Charades game in teaching vocabulary is more effective than the conventional technique. From the two classes, the experimental and control group, the measurement shows that increasing line of the vocabulary mastery of the experimental group is higher than the control group. There is also a significant influence of students in vocabulary mastery before and after being taught by using Charades game at eighth grade SMP Muhammadiyah Ahmad DahlanMetro. It is proved by the game can help the students to manage their emotions. They should not be nervous when acting out the words. Last, it can decrease the number of students who are lazy in the classroom.

In addition, the Charades Game can increase the students' vocabulary mastery effectively due to some reasons. It can increase students' motivation because students will work hard to act out and guess the right answer to win the game. It overcomes students' boredom in learning vocabulary because students like something enjoyable and fun.

hypothesis testing indicates that the post-test result of the experimental group is significantly higher than the post-test obtained in the control group. Based on the result of the investigation, it is found that the use of Charades Game is effective to increase the students' speaking skill. It means that the teaching vocabulary by using the Charades Game at eighth grade SMP Muhammadiyah Ahmad Dahlan Metro gives a significant influence on their speaking ability. 


\section{ACKNOWLEDGEMENT}

Alhamdulillahirobbil'alamin, highest praise to Allah subhanahuwata'ala for love, opportunity, health, and happiness to complete this undergraduate thesis entitled "The Effectiveness of Using Charades Game Toward Students' Vocabulary Mastery". Peace and bless always given for the Greatest Prophet Muhammad SAW who has brought from the stupidity into this cleverness era. This undergraduate thesis is submitted as the partial requirement in accomplishing undergraduate degree at English Education Study Program of Teacher Training and Education Faculty, Muhammadiyah University of Metro.

Many people give the motivation, advice and support for the researcher to accomplish this research. The first for Drs. H. Jazim Ahmad, M.Pd as the rector of Muhammadiyah University of Metro, Drs. Partono, M.Pd as the Dean of Teacher
Training and Education Faculty, and Mr. Amirudin Latif, M.Pd as the head of the undergraduate English Education Study Program.

This article would not have been possible to finish without many bits of help, guidance, supports and advises from the wise and patience to all lecturers. They have given their time to help to finish this undergraduate thesis by giving motivation, guidance, suggestion and correction for the researcher.

Finally, the researchers must realize that this research is far from the completeness. Although this research is far from perfect, the researcher hopes that it will be useful for all of the people not only for researchers but also for the readers especially for the students who want to learn vocabulary mastery.

\section{REFERENCES}

Arikunto. 2010. Prosedu rpenelitian: suatu pendekatan praktek. Rinekacipta. Jakarta.

Aslanabadi, h. \&rosauli, g. 2013. The effect of games on the improvement of Irani EFL vocabulary knowledge in kindergartens. International review of social sciences and humanities. 6(1), p. 186-195

Bafadal, f.m. 2018. The use of charades games in teaching vocabulary to the junior high school students. Linguistics and elt journal, 6(2) p. 365-134 
Banerjee, S. 2014. Learn and unlearn: drama as an effective tool in teaching English language and communication. International journal of English language \& translation studies, 2(3) p. 140

Brown, H.D. 2010. Language assessment: Principle and Classroom.Practice. New York: Pearson Education

Hanson \&padua. 2011. Teaching vocabulary explicitly. Pacific resources for education and learning. London: oxford university.

Hariadi, i\&amir, z. 2014. Teaching English vocabulary through k.i.m (keyword, information, and memory clue) vocabulary strategy in junior high school.ELT Journal, 2(2) p, 111119

Hidayati, n.r. 2015. The use of charades game to teach vocabulary. Elt forum: journal of English language teaching, 5(1),p. 235

Himmele, P. 2011. Total Participation Techniques: Making every student an active learner. Alexandria, Va: ASCD

Newman, s.b., \&dwyer, j. 2010. Missing in action: vocabulary instruction. Pre-k. The reading teacher. 62(5), p. 385.

Nurdini, h. \&marliana, 1. 2017. Vocabulary journal as a learning tool for students in learning vocabulary through reading at junior highschool. Journal of English language teaching, 6(1) p. 221

Orawiwatnakul, W. 2013. Crossword Puzzles as a Learning Tool For Vocabulary Development. Electronic Journal of Research in Education Psychology, 11(2), p. $413-$ 428

Rafinggi, d.1. \&ikhsan, m.k. 2013. Teaching vocabulary by using charades techniques for young learners. Available at ejournals1, 2(2) p.15

Septiana, M. 2018. The Influence of Using Charades Game Towards Students Vocabulary Mastery At The First Semester Of The Eighth Grade Of SMPN 1 Pesawaran. Unpublished Thesis. Bandar Lampung: English department of State Islamic University of Raden Intan Lampung

Setiadi. 2013. Konsep dan Praktik Penulisan Riset Keperawatan. Yogyakarta: Grahallmu.

Sudjana, Nana. 2011. PenilaianHasildan Proses BelajarMengajar. Bandung: Rosdakarya

Sugiyono. 2016. Metode penelitian pendidikan pendekatan kuantitatif, kualitatif, dan $r \& d$. Alfabeta. Bandung.

Syarfuni. 2010. The implementation of a game in teaching English vocabulary. Visipena journal, 1(2) p. 113-120

JEE (Journal of English Education) Vol. 6 No. 2, December 2020

http://journal.upp.ac.id/index.php/JEE

P-ISSN:2459-9719, E-ISSN 2597-7091

DOL: https://doi.org/10.30606/jee 
Wiersma, W., \&Jurs, S. 2010. Research methods in education: An introduction. MA: Pearson

Yunus, M.M., Yen, L., Aina H.M. \&Norsharina, M.Y. 2020. Acquisition of Vocabulary in Primary Schools Via Gopic With QR Code. International Journal Of English Language and Literature Studies, 9(3), p. 121-131. 